\title{
Effect of dietary energy and protein on performance of guinea fowl reared in the humid tropics of Nigeria
}

Odukwe, C. N., Ukachukwu, S. N. Onunkwo, D. N. and Oke, U. K.

${ }^{1}$ Department of Animal Nutrition and Forage Science, College of Animal Science and Animal Production, Michael Okpara University of Agriculture, Umudike,

Umuahia,

Abia State, Nigeria.

Abstract*Corresponding author's email: donunkwo1@gmail.com@gmail.com

The effects of varying levels of energy and protein on optimal performance of helmeted guinea fowl and carcass characteristics were investigated. Three hundred and twenty-four 7week old guine a fowls were randomly allotted to treatments in a $3 \times 3$ factorial arrangement of a Completely Randomized Design. The birds were respectively assigned to the experimental diets of $10.46 \mathrm{MJ}, 10.87$ and $11.29 \mathrm{kcal}$ of $\mathrm{ME} / \mathrm{kg}$ diet with a corresponding protein content of 15, 16, and 17\% CP. They were fed these diets from 7 to 12 weeks of age. Each dietary treatment had four replicates of 27 birds per replicate. Feed and water were provided adlibitum. The birds were observed for feed consumption, weight gain, final weight, water consumption and mortality. There were significant $(P<0.05)$ energy $x$ protein interaction effect for the average final weight with birds on $10.87 \mathrm{MJ} / \mathrm{kg} \times 15 \% \mathrm{CP}$ for $\mathrm{FW}$ and also for energy $x$ protein main effects for FI, WI and $W G$. There were significant $(P<0.05)$ energy main effects and energy $x$ protein interaction for gizzard weight, back weight and breast weight with constant energy levels of $10.87 \mathrm{MJ} / \mathrm{kg} \mathrm{ME}$ and $10.46 \mathrm{MJ} / \mathrm{kg} \mathrm{ME}$ at their interaction level. Birds on $11.29 \mathrm{MJ} / \mathrm{kg} \mathrm{MEx} 15 \mathrm{CP}$ and $11.29 \mathrm{MJ} / \mathrm{kg} \mathrm{MEx} \mathrm{17 \% CP} \mathrm{gave} \mathrm{the}$ heaviest gizzard of 922.66 and 19.09 and in other parameters, except in Neck weight which shows no significant $(p<0.05)$ energy and protein as well as the energy $x$ protein interaction. But there were significant energy main effect and no significant protein main effects for wing weight as well as significant differences $(p<0.05)$ energy and protein main effects on total dressed with 10.887MLkg MEX 17\% CP gave the highest value of 717.22g. There was also a significant $(p<0.05)$ interaction effects on average live weight with $11.29 \mathrm{MJ} / \mathrm{kg} \mathrm{ME} x$ $15 \% \mathrm{CP}$ diet gave the highest value of $1.48 \mathrm{~kg} / \mathrm{bird}$. The findings from this study that 10.87 $M J / k g ~ M E$ and $15 \% C p$ diet gave the best performance.

Keywords: Dietary energy and protein, performance, guinea fowls, humid tropics

\section{Introduction}

Helmeted guinea fowls are the most omnivorous of the guinea fowl species, consuming a wide range of plant and animal materials (even some toads), switching their preferences to whatever appears to be abundant at the time, but focusing on insect and arthropods during the breeding season. The quality of the bird at the onset of her production cycle will greatly determine how profitable she will be during the period of lay (Nahashon et al., 2007). Special emphasis must therefore be placed on feeding the growing bird so that she may develop to its full genetic potential (Bell and Weave, 2002). The general consent stipulates determination of nutrient requirements of different types of poultry to efficiently utilize their genetic potential for specific production goals (PYM, 1990). Several studies have evaluated the Metabolizable Energy (ME) and crude protein requirements of the guinea fowl; however they are quite inconclusive and most cover the period from 0 to 16 week of age. They reported that for the growing 


\section{Effects of dietary energy and protein on performance of Guinea fowls reared in the humid tropics of Nigeria}

guinea fowl, the diet should contain about $3,010 \mathrm{kcal}$ of $\mathrm{ME} / \mathrm{kg}$ of diet and 24 to $26 \% \mathrm{CP}$ at 0 to 4 week of age, $3,010 \mathrm{kcal}$ of $\mathrm{ME} / \mathrm{kg}$ diet and 19 to $20 \% \mathrm{CP}$ at 5 to 8 weeks and 3,010 kcal of ME/ $\mathrm{kg}$ of diet and CP concentration of $16 \%$ or less at 8 to 12 weeks of age. This necessitates the search to evaluate optimum ME and CP for growth performance and egg product. Providing adequate $\mathrm{ME}$ and $\mathrm{CP}$ will in part have an important bearing on the bird's productivity during the laying period (sales and Pereez, 1997; Oke et al., 2003; Nahashon et al., 2004). Studies of the nutritional requirement of intensively kept birds suggested that growth performance up to 12 weeks of age is not significantly affected by different ME levels (Singh 1994). Singh (1994) reported that keets were able to adjust their energy intake within a range of $2,700 \mathrm{kcal}$ to $3,000 \mathrm{kcal} / \mathrm{kg}$ of feed. Also the live weight gains were linear with increasing dietary protein levels at all ages. Singh 1994 also reported that the effect of dietary treatments on live weights and weight gain was highly significant at 8 weeks of age. Also at 12 weeks of age, energy and protein interaction had no effect on live weight (Singh, 1994). The nutrient requirements of the guinea fowl have however been assumed to be same as that of the chicken as regards the major nutrients (Oluyemi's 1982). Insects form a component feature in the guinea fowl diet, especially in the weight season which coincides with the breeding season. This suggests that protein and energy rich components predominate in the diets and are necessary for maintenance of the daily activities of the birds (Tewe, 1993). Although, the assessment of calories and protein requirements appears to be the most critical for many reasons, these two components attract the highest cost in livestock feed and also form the largest bulk by weight of compounded rations.

Dietary metabolizable energy (ME) composition has a major impact on body composition of chicken Collin et al. (2003) as well as the guinea fowl. Ayeni (1980) and Nahashon et al. (2005) reported that semidomesticated guinea fowl keets were found to perform best on $20-24 \%$ crude protein diet and could be reduced to $18 \%$ by eight weeks of life. Protein levels between 14\% and $15 \%$ and $\mathrm{ME}$ of $3000 \mathrm{kcal} / \mathrm{kg}$ may be sufficient from 12 weeks and above. Therefore, the objective of this study is to evaluate the optimum energy and protein level for best growth performance of guinea fowl

\section{Materials and methods}

A total of three hundred and twenty-four 7 weeks old guinea fowls were used to fowls evaluate the effect of energy and protein levels on the performance and carcass quality characteristics of guinea fowl in a $3 \times 3$ factorial in a completely Randomized Design. The birds were subjected to three energy levels $(10.46,10.87$ and $11.29 \mathrm{MJ} / \mathrm{kg}$ $\mathrm{ME})$ and three protein levels $(15,16$, and $17 \% \mathrm{CP}$ ) as main factors and were replicated 3 times weight gain, feel intake, water intake were measured while feed conversion ration SP was calculated. Feed and water were given to the birds ad-libitum and the experiment lasted 5 weeks. The percentage composition of the experimental diets and their proximate composition are presented in Table 1 and 2 respectively.

The $15 \% \mathrm{CP}$ level diet produced the highest daily weight gain of $(5.45 \mathrm{~g} / \mathrm{d} / \mathrm{b})$ followed by $16 \%$ diet while the $17 \% \mathrm{CP}$ produced the lowest $(\mathrm{P}<0.05)$ DWG. The decreasing trend in weight gain as protein level increased because feed intake is a major factor that influences both the body weight gain and efficiency in meat-type poultry (Nahashon et al., 2006; Nkafamiya et al., 
Odukwe, Ukachukwu, Onunkwo and Oke

Table 1: Composition of the experimental diets containing different energy and protein levels

\begin{tabular}{|c|c|c|c|c|c|c|c|c|c|}
\hline & $\mathbf{E}_{1} \mathbf{P}_{1}$ & $\mathbf{E}_{1} \mathbf{P}_{2}$ & $\mathbf{E i P}_{3}$ & $\mathbf{E}_{2} \mathbf{P}_{1}$ & $\mathbf{E}_{2} \mathbf{P}_{2}$ & $\mathbf{E}_{2} \mathbf{P}_{3}$ & $\mathbf{E}_{3} \mathbf{P}_{1}$ & $\mathbf{E}_{3} \mathbf{P}_{2}$ & $\mathbf{E}_{3} \mathbf{P}_{3}$ \\
\hline Maize & 18.30 & 9.45 & - & 17.41 & 8.8944 .46 & & 16.53 & $8.62-$ & \\
\hline $\begin{array}{l}\text { Maize } \\
\text { offal }\end{array}$ & 36.60 & 37.81 & 44.34 & 39.17 & & 53.35 & 41.32 & 38.81 & 43.60 \\
\hline $\mathrm{P} / \mathrm{CC}$ & 36.61 & 47.27 & 35.47 & 30.47 & 35.57 & 36.68 & 24.80 & 35.47 & 34.88 \\
\hline GNC & 5.29 & 2.27 & 8.12 & 9.75 & 7.88 & 7.88 & 14.15 & 10.56 & 9.61 \\
\hline $\begin{array}{l}\text { Bone } \\
\text { Meat }\end{array}$ & 2.50 & 0.252 .50 & 2.50 & 2.50 & 2.20 & 2.20 & 2.20 & 2.20 & 2.20 \\
\hline Premix & 2.20 & 2.20 & 2.20 & 2.20 & 2.20 & 2.20 & 2.20 & 2.20 & 2.20 \\
\hline $\mathrm{Nacl}$ & 2.20 & 2.20 & 2.20 & 2.20 & 2.20 & 2.20 & 2.20 & 2.20 & 2.20 \\
\hline Total & 100 & 100 & 100 & 100 & 100 & $100^{\prime}$ & 100 & 100 & 100 \\
\hline $\mathrm{CP} \%$ & 15.00 & 15.00 & 15.00 & 15.00 & 16.00 & 16.00 & 16.00 & 17.00 & 17.00 \\
\hline
\end{tabular}

$\mathrm{E}_{1} \mathrm{P}_{1}=$ Energy and protein $10.46 \times 15$
$\mathrm{E}_{1} \mathrm{P}_{2}=$ Energy and protein $10.46 \times 16$
$\mathrm{E}_{1} \mathrm{Ps}=$ Energy and protein $10.87 \times 17$
$\mathrm{E}_{2} \mathrm{Pi}=$ Energy and protein $10.87 \times 15$
$\mathrm{E}_{2} \mathrm{P} 2=$ Energy and protein $10.87 \times 16$
$\mathrm{E}_{2} \mathrm{P} 3=$ Energy and protein $10.87 \times 17$
$\mathrm{E}_{3} \mathrm{Pi}=$ Energy and protein $11.29 \times 15$
$\mathrm{E}_{3} \mathrm{P}_{2}=$ Energy and protein $11.29 \times 16$
$\mathrm{E}_{3} \mathrm{P}_{3}=$ Energy and protein $11.29 \times 17$

2007).

There were significant $(\mathrm{P}<0.05)$ protein main effect. Protein intake value of $15 \% \mathrm{CP}$ diet was the highest (8.11) followed by $16 \% \mathrm{CP}$ while that of birds on $17 \% \mathrm{CP}$ diet was the lowest (4.58). This shows that consumption of diets decreases as level of dietary protein increases. This shows that the protein requirement of growing guinea fowls is met at $15 \% \mathrm{CP}$ dietary level. With regards to energy $\mathrm{x}$ protein interaction, birds on $15 \%$ CP dietary level. With regards to energy $\mathrm{x}$ protein interaction, birds on $15 \% \mathrm{CP} \times 10.87 \mathrm{MJ} / \mathrm{kg} \mathrm{ME}$ and $15 \% \mathrm{CP} \times$ $11.29 \mathrm{MJ} / \mathrm{kg} \mathrm{ME}$ diets had similar but highest intake values, followed by birds on $15 \% \mathrm{CP} \times 11.29 \mathrm{MJ} / \mathrm{kg} \mathrm{ME} ; 16 \% \mathrm{CP} \times 10.46$ $\mathrm{MJ} / \mathrm{kg} \mathrm{ME}$ and 17\% Cp x $10.46 \mathrm{MJ} / \mathrm{kg}$ diets, which were similar.

Birds on $17 \% \mathrm{CP} \times 10.87 \mathrm{MJ} / \mathrm{kg} \mathrm{ME}$ and $17 \%$ x $11.29 \mathrm{MJ} / \mathrm{kg}$. ME diets had similar but lowest feed intakes. This observation is consistent with the report of Nahashon et al. (2006), which state that birds consume feed primarily to meet their body $\mathrm{ME}$ requirement. The rate of feed consumption decreases when birds are fed a high energy diet (Nahashon et al., 2005) due to heat increment, which does not encourage high feed intake but rather encourage high water intake.

Nahashon (2006) also suggested that the effect of dietary energy on performance of growing birds is dependent on the bird's capacity to alter feed intake to meet changing demand for calories. Previous studies (Plavnik et al., 1997; Nahashon et al., 2005) have also suggested that as dietary energy increases, birds satisfy their energy needs by decreasing feed intake. Decreased feed intake with high energy in the diets is supported by Veldkamp et al. (2005) which also observed that feed conversion ration (FCR) were significant (PO.05) protein and energy Birds that consumed $17 \% \mathrm{CP}$ diets had the poorest FCR followed by those fed 15 and $16 \% \mathrm{CP}$ diets which were similarFCR of birds onlO.46 MJ/kg ME diet was similar to that of birds on $11.29 \mathrm{MJ} / \mathrm{kg} \mathrm{ME}$ diets but poorer 

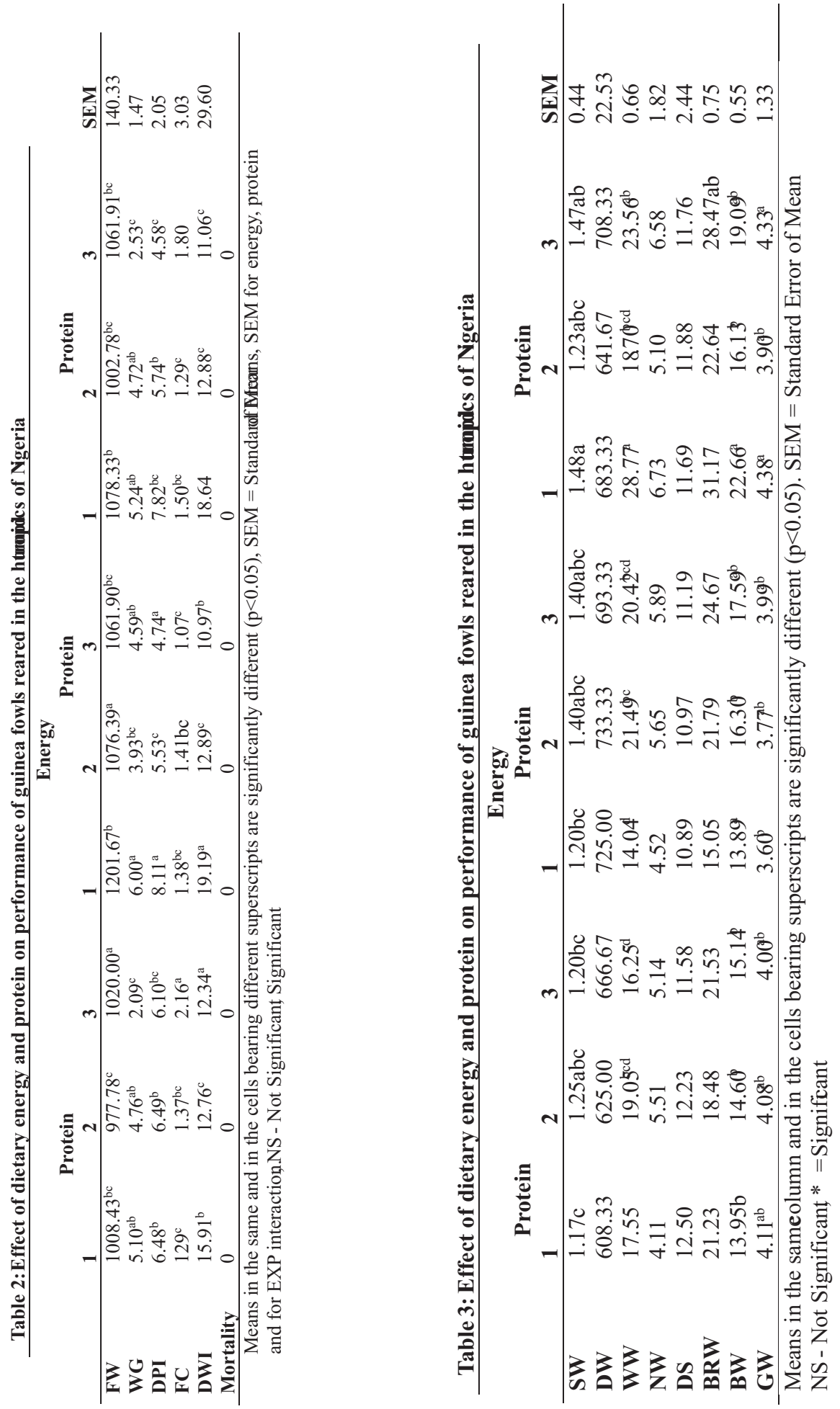


\section{Odukwe, Ukachukwu, Onunkwo and Oke}

than the FCR of birds on $10.87 \mathrm{MJ} / \mathrm{kg}-\mathrm{ME}$ diet. There was significant $(\mathrm{P}<0.05)$ energy $\mathrm{x}$ protein interaction effect. effect of 10.87 $\mathrm{MJ} / \mathrm{kg} \mathrm{ME}$ and $17 \% \mathrm{CP}, 10 . \$ 6 \mathrm{MJ} / \mathrm{kg}$ x 15\% $\mathrm{CP}$ and $11.29 \mathrm{MJ} / \mathrm{kg}$ x $16 \% \mathrm{Cp}$ gave the best FCR of 1.07. Birds fed diet containing $10.46 \mathrm{MJ} / \mathrm{kg}$ and $17 \mathrm{CP}$ had the lowest FCR, FCR influence the biological components of the birds. This is accordance with the ratio of calories to protein as verified by remarkable effect on biological productivity, physiological well being and carcass composition. Feed conversion ratios which ranged between $1.07-2.16$ recorded in the current study are lower than the recommended values; 3.5 - 4.5 (lesson, 2000). Nagu and Alawa (1995) argued that the wild behavior of guinea fowls the characteristic timid but very active. Flighty and noisy temperature contributes to poor feed conversion efficiency through high energy output. The lower FCR recorded in this experiment could be because the birds were raised under confined condition. The average daily water intake (ml/day/bird) of the guinea fowls as influence by dietary energy and protein level were significantly different $(\mathrm{P}<0.05)$ protein $\mathrm{x}$ energy interaction effects. Highest significant means of daily water obtained from $15 \%$ CP x $10.87 \mathrm{MJ} / \mathrm{kg} \mathrm{ME}$ and 15\%CP x 11.29 $\mathrm{MJ} / \mathrm{kg} \mathrm{ME}$ interactions followed by $15 \% \mathrm{CP} \times 10.46 \mathrm{MJ} / \mathrm{kg}$ interactions. The $16 \% \mathrm{CP}$ and $17 \% \mathrm{CP}$ interactions with all the three energy levels had similar but the lowest water intake. Water requirement of guinea fowls is most likely to be met with varying energy levels while keeping the protein level constant at $15 \% \mathrm{CP}$. This means that energy level had no significant effect on water intake.

Energy and protein interaction showed no significant effect on mortality. The cause of zero mortality may be largely due to the nutrient combinations which can be judged safe and satisfactory for the survivability of guinea fowls. This observation agrees with the findings of Embury (2001) who report that survival rate of keets is remarkably improved through proper brooding and feeding. Marizuikuru et al. (2008) also reported an insignificant mortality of $5 \%$ in their study.

\section{Conclusion and Recommendation}

The effect of different energy and protein levels on the growth performance and carcass quality of the guinea fowls showed that $10.87 \mathrm{MJ} / \mathrm{kg} \mathrm{ME}$ and $\mathrm{Cp}$ diet gave the highest significance effects on the performance of guinea fowls and also gave the highest dressed weight. Therefore, it would be appropriate to feed guinea fowls raised in the humid tropics with energy diet of $10.87 \mathrm{MJ} / \mathrm{kg} \mathrm{ME} \mathrm{x} \mathrm{15 \% CP} \mathrm{for} \mathrm{optimum}$ growth parameters. The significant increase in body weight is consistent with the findings of Nsoso et al. (2003; 2006) where guinea fowl had similar live weight at the same stage of growth and development. They have slow growth rate compared to broilers which reach 1.5 to $2 \mathrm{~kg}$ in $6-8$ weeks. The continuous increase in the neck length is adaptive feature to the environment to enable birds have clear view of their surrounding and to detect any danger and/or see their predators in advance. Since the energy $x$ protein interactions was not significant. It implies that any of the combinations of $\mathrm{ME}$ and $\mathrm{CP}$ can be used to produce average neck weight which is an adaptive feature to see their predators in the wild. The energy and protein on the drum stick weight did not differ significantly $(p<0.05)$ on both interaction and main effects. This observation indicates that drum stick weight could be achieved using any of the dietary combinations of ME and $\mathrm{CP}$. This trend suggests early maturing trait and this 
is supported by the fact that a strong drum sticks and its weight are needed to support the whole body frame.

\section{References}

Alawa, C. B. and Nwagu, B. I. 1995. Guinea fowl production in Nigeria. World poultry Sci. J. 51:261-269. Available at htt:/www.cipv.org.co/irrd/irrd!8/ 12/nsos/1817. htm.

Nahashon, S. N., Adefope, N. A., Amenyenu, A. and Wright. D. 2007. Effect of varying concentrations of dietary crude protein and metabliolization energy on laying performance of pearl; grey guinea fowl hens. Poult Sci. ASSO 86:1793-1799.

Bell, D. E. and Weave, W. D. 2002. Feeding commercial egg type layers 287-328. In commercial chicken meat and egg production, bell, D. E. and Weaver, W.D. (Eds). Cluwer Academic publishers the Netherlands.

Pym, R. A. E. 1990. Nutritional Gentiles, pp 847-876 In: poultry breeding and genetics Crawford, R.D. (Ed). Elsevier publishing Co, New York NY.

Sale, J. and D. U. Perez, J. I. 1997. Protein and energy requirements of the pearl Gray Guinea fowl Words poult Sci. J. 53:382-385.

Oke, U. K., Herbert, U. and Akinimutimi, A. H. 2003. Early Lay characteristics and Hematology of Pearl Guinea Fowls as Influenced by Dietary Protein and Energy levels. Int'l Poult. Sc.. 2:128-132.

Nahashon, S. N., Amenyenu, A., Muhammad, S., Adefope N. and Wright W. 2004. Assessment of Awareness and Constraints in Production of Guinea Fowl in Tennessee and other parts of the United States. South Anim. Sc. Assoc. Tulsa. Ok. 28:7.

Singh, R. P. And Kumar, J. 1994. Biometrical Method in Poultry Breeding. Ludkhiane, Kalyam Publishers. $240 \mathrm{Pp}$.

Singh, H. 1994. Relevance of Guinea Fowl for Rural Poultry Farming. XVI AnimPoutry. Sci. Symp. and Conf (Held 9-11 Feb., 1994). Bhubaneswar.

Oluyemi, J. A. 1982. Management of Turkey, Duck, Geese, Guinea Fowl and Game Birds. Mongraph. Department of Animal Science. University of Ibadan, Nigeria.

Tewe, O. O. 1993. Thyroid Cassava Toxicity in Animal proceedings of a Workshop, Ottawa 10RC207e:1140118p.

Colin, A., Malheros, R. D., Moraes, V. M. B., Van, A. S. P., Daras, V. M., Taui. Deculpere E. and Byse, J. 2003. Effect of Dietary Macronutrient Content on Energy Metabolism and Uncoupling Protein MRNA Expression in Broiler Chicken. Br. J. Nutr. 90:261. (151) Medline.

Nahashon, S. N., Adefope, N., Ammenyenu, A. and Wright D. 2005. Effect of Dietary Metabolizable Energy and Crude Protein Concentration on Growth Performance and Carcass Characteristics of French Guinea Breiters. Poult. Sc. 84:337-344. 
Ayeni, J. S. O. 1980. The Biology and Utilization of Helmey Guinea F o w $1 \quad(\mathrm{~N} \mathrm{u} \mathrm{m} \mathrm{i} \mathrm{d} \mathrm{i} \mathrm{a}$ MeleagrisGaleata Pallas. Ph.D. Thesis, University of Ibadan, Ibadan, Nigeria.

Nahashon, S. N., Adefope, N., Ammenyenu, A. and Wright D. 2006. Effect of varying metabolizable energy and crude protein concentrations in diets of pearl gray guinea fowl pullets. Growth performance poult. Sci. 85:1847-1854.

Nkafamiya, 1. 1., Osemeaho, S. A., Dahiru, D. and Umaru, H. A. 2007. Studies on the Chemical Composition and PhysioChemical Properties of Baobad (Adasoniadigitata), Afr. $J$. Biotech: 6:756-759.

Planvik, L. E., Wax, D. Sklan, I., Bartov and S. Hurwitz 1997. The Response of Broiler Chicken and Turkey Poult to Dietary Energy supplies either by Fat or carbohydrates. Poult. Sci. 76:1000-1005.

Veldkamp, T. R. P., Kwakkel, P. R., Ferket and Verstegen, M. W. A. 2005. Growth Response to Dietary Energy and Lysine at High and Ambient Temperature in Male Turkey. Poult.Sci. 84:273-282.

Lesson, S. 2000. Is Feed Efficiency still Useful Measure of Broiler Performance? Department of Animal and Poultry Science, University of Guelph, Ministry of Agriculture, Food and $\mathrm{R} \mathrm{ura} 1$ a f $\mathrm{fa}$ i $\mathrm{rs}$, Canada.http://www.omafra.gov. oncalenght/livestock/poultrv/fa cts/efficiencv.htni.
Embury, I. 2011. Raising gunea fowl. Ag. fctA. S. 0.8 narsuth. Watr Agriculture. Publications. USA. IP:4.

Nsoso, S. J., Seabo, G. M., Gosiemang, Molathegi, S. G. Mokobela, M. Ghabo, R. O. and Mine, O. M. 2003. Performance of Progeny of Wild and Domesticated G u i n e a $\quad$ F o w 1 (NumdaMelagris)inSouthernBo tswana.South Africa. Anim. Sci. $4: 4651$. http://ww w sasa.co.zaicienscitific/nsosoB. pdf.

Nsoso, S. J., Mareko, M. H. D and Olelekwa, C. 2006. Comparison of Growth and Morphological Parameters of Guinea Fowl (Nkumdameleagri) raised on Concentrate and Earth Floor Furnishes in Botswana. Livestock research for rural development 18(12)2006.

Mirizvikuru M., Mupangwa, J. F. Mapiye, C., Saina H. and Clumivuramahwe, J. 2008. Growth Performance of Guinea Fowl Keets Fed Graded Levels of Boabad Seed Cake Diets. Int'l Poult. Sc. 7. (50)429-432.

Received: $25^{\text {th }}$ August, 2016 Accepted: $12^{\text {th }}$ March, 2017 